\title{
Adaptation patterns of sixteen alfalfa (Medicago sativa L.) cultivars across contrasting environments of Algeria and implications for the crop improvement
}

\author{
Chahira Achir, ${ }^{1}$ Paolo Annicchiarico, ${ }^{2}$ Luciano Pecetti, ${ }^{2}$ Houssem-Eddine Khelifi, ${ }^{1}$ \\ Mahfoud M'Hammedi-Bouzina, ${ }^{3}$ Aissa Abdelguerfi, ${ }^{4}$ Meriem Laouar ${ }^{1}$ \\ ${ }^{1}$ Laboratory of Integrative Improvement of Vegetal Productions, Higher National Agronomic School \\ (ENSA), Algiers, Algeria; ${ }^{2}$ Council for Agricultural Research and Economics (CREA), Research Centre for \\ Animal Production and Aquaculture, Lodi, Italy; ${ }^{3}$ Laboratory of Local Natural Bio-Resources, University \\ Hassiba Benbouali of Chlef, Chlef, Algeria; ${ }^{4}$ Cité des Annassers, Algiers, Algeria
}

\begin{abstract}
The additive main effects and multiplicative interaction analysis was applied to assess the genotype $\times$ environment interaction (GEI) effects and stability for 4-year dry matter yield (DMY) of 16 alfalfa (Medicago sativa L.) cultivars of diversified geographic origin grown in four Algerian environments given by the combination of two water managements (rainfed and irrigated) and two evaluation sites, viz. the sub-humid location of Alger and the semi-arid, salinity-affected site of Hmadna. The analysis of variance (ANOVA) revealed significant variation among cultivars and environments $(\mathrm{P}<0.001)$. The GEI was significant $(\mathrm{P}<0.001)$ and the environment main effect had greater influence than the genotype effect on long-term yield according to ANOVA. Rainfed con-
\end{abstract}

Correspondence: Chahira Achir and Meriem Laouar, ENSA, Avenue Hassan Badi, El Harrach 16004, Algiers, Algeria.

E-mail: chahira.achir@gmail.com; m.laouar@ensa.dz

Key words: AMMI analysis; drought tolerance, dry matter yield; genotype x environment interaction; Medicago sativa L.; yield stability.

Acknowledgements: our thanks are extended to the EU-funded project PERMED (Improvement of native perennial forage plants for sustainability of Mediterranean farming systems) (INCO-CT-2004-08, PL509140), and to all people who participated during the execution of the experiment, both for management of the trials and data collection.

Contributions: PA, LP and AA, designed the study and the experiments. $\mathrm{HK}, \mathrm{MMB}, \mathrm{AA}$ and ML, collected the data. CA, PA and ML, carried out the statistical analysis and interpretation of results. CA, wrote the manuscript. LP, PA and ML, collaborated on the final drafting of the manuscript.

Received for publication: 11 December 2019.

Revision received: 18 February 2020.

Accepted for publication: 18 February 2020.

(C) Copyright: the Author(s), 2020

Licensee PAGEPress, Italy

Italian Journal of Agronomy 2020; 15:1578

doi:10.4081/ija.2020.1578

This article is distributed under the terms of the Creative Commons Attribution Noncommercial License (by-nc 4.0) which permits any noncommercial use, distribution, and reproduction in any medium, provided the original author(s) and source are credited. ditions had $41.6 \%$ and $48.5 \%$ lower yield than the irrigated ones in Alger and Hmadna, respectively. Alfalfa cropping in the semiarid location caused lower DMY than in the sub-humid one ( $-38.0 \%$ under irrigated and $-45.2 \%$ under rainfed conditions) and a slightly lower persistence over the 4-year period. Outstanding environment-specific cultivar responses were observed, fully justifying the large GEI effects, although the Italian cultivar Sicilian ecotype had remarkable yield stability and good mean yield. The American variety Ameristand $801 \mathrm{~S}$ and the Moroccan landrace Erfoud 1 were the most salt-tolerant cultivars. The evaluated germplasm, and particularly some exotic cultivars, could be used as parents to breed new varieties more adapted to drought and salinity in the Mediterranean basin.

\section{Introduction}

The predicted greater incidence of drought caused by climate change (Alessandri et al., 2014) will affect the productivity of crop-livestock systems in the Mediterranean region (Volaire et al., 2014), where drought during late spring and summer is the prominent stress (Annicchiarico et al., 2011). Drought is considered the main cause of low crop yields in Algeria (Bellague et al., 2016). In addition to water deficit, salinisation is also frequent in Mediterranean environments (Fagnano and Maggio, 2018), owing to the presence of naturally saline soils (Small, 2010) or to irrigation with saline water (Pecetti et al., 2013), with important impacts on the economy of affected countries.

Alfalfa (Medicago sativa L.) is the world's most important forage crop and it is the main perennial forage legume in most temperate regions (Annicchiarico et al., 2015). It is an energy-efficient, environmentally-friendly crop, owing to its biological nitrogen fixation and the subsequent reduction in nitrogen application that it enables (Ballesta and Lloveras, 2010). The adoption of alfalfa as a forage crop could improve the economic and environmental sustainability of crop-livestock systems in the Mediterranean basin (Annicchiarico et al., 2011). Despite the potential of alfalfa, its growing area in Algeria is still limited compared to other crops (Chedjerat et al., 2016).

Alfalfa can extend the forage production into early summer and autumn in dry-land Mediterranean environments (del Pozo et al., 2017), although drought and temperature extremes are the most important limitations during the growing season (Abdelguerfi and Laouar, 2002). Variation does exist in the species, though, for adaptation to either low or high temperatures (Annicchiarico et al., 2015) as well as to drought, thanks to mor- 
pho-physiological mechanisms (Annicchiarico et al., 2013, 2015). Although rated as moderately susceptible to salinity (Pecetti et al., 2013), alfalfa is often challenged by the saline stress in dry Mediterranean areas (Chedjerat et al., 2016). Variation can be found for tolerance to this stress during the germination stage (Benabderrahim et al., 2011).

Alfalfa breeding and variety recommendation should therefore be primarily driven by the prevailing environmental conditions of the target area(s). The additive main effects and multiplicative interaction (AMMI) and Genotype main effects and genotype $x$ environment interaction (GGE) are the most used models for statistical analyses in yield trials where several genotypes are typically tested in various environments (Gauch et al., 2008). The AMMI model subdivides the overall variation into genotype $(\mathrm{G})$ main effects, environment $(\mathrm{E})$ main effects, and genotype $\times$ environment interaction (GEI) effects, thus considering separately those three sources of variation (Gauch, 2006; Gauch et al., 2008). This is particularly relevant in plant breeding programmes where GEI is a substantial component to deal with (Barrios et al., 2017). Because of the importance of GEI, genotypes must be assessed in multienvironment trials to choose the best one(s) to use as new culti$\operatorname{var}(\mathrm{s})$ or as breeding material (Annicchiarico, 2002).

The need to provide drought- and salt-tolerant germplasm to cope with the growing challenges that the crop is facing in North Africa, and the ultimate aim of increasing the alfalfa cropping area in Algeria, suggested undertaking the present study. We assessed the GEI effects of 16 alfalfa cultivars and analysed their adaptation in terms of forage yield to contrasting environments of Algeria, with the purpose of defining elite germplasm for future breeding of stress-tolerant varieties targeted to Mediterranean environments.

\section{Materials and methods}

\section{Experimental data}

Sixteen alfalfa cultivars, including landraces and varieties of different geographic origin such as Europe, North Africa, USA and Australia (Table 1), were evaluated in two locations in Algeria (Alger and Hmadna) under two water managements, namely, rainfed conditions and under sprinkler irrigation with water withheld in summer for nine weeks (Table 2). The main climatic and soil characteristics of the two locations are reported in Table 2. Although lying at a similar altitude of about $50 \mathrm{~m}$ above sea level, Alger features a sub-humid Mediterranean climate, whereas Hmadna is characterised by a semi-arid climate. In addition, Hmadna showed high soil electrical conductivity $\left(5.2\right.$ to $\left.6 \mathrm{dS} \mathrm{m}^{-1}\right)$ compared to Alger $\left(1.9 \mathrm{dS} \mathrm{m}^{-1}\right)$.

Each combination of location and water management (termed as environment) was arranged in a randomised complete block design with four replications. The elementary plot area was $5 \mathrm{~m}^{2}$ $(2 \mathrm{~m} \times 2.5 \mathrm{~m})$, including 10 rows with $20 \mathrm{~cm}$ spacing. Hand-sowing was carried out at the end of November 2004 with a seed rate of $25 \mathrm{~kg} \mathrm{ha}^{-1}$, after a fertilisation with $92 \mathrm{~kg} \mathrm{ha}^{-1}$ of $\mathrm{P}_{2} \mathrm{O}_{5}$.

A harvest area of $2.4 \mathrm{~m}^{2}$ including the six central rows of $2 \mathrm{~m}$ length, was mown to a height of $5 \mathrm{~cm}$ from the ground in each plot when $75 \%$ of the overall plants in the trial reached a height of 30 to $35 \mathrm{~cm}$ in the winter season, or after onset of flowering of $75 \%$ of the cultivars in the spring season. The dry matter yield (DMY) was obtained after oven-drying at $80^{\circ} \mathrm{C}$ for $48 \mathrm{~h}$ the aerial biomass from the harvested area. The cumulated DMY was computed over four years of evaluation from November 2004 to July 2008.

\section{Statistical analysis}

A combined analysis of variance (ANOVA) was carried out to assess GEI and stability of the cultivars across environments and the least significant difference (LSD) at $\mathrm{P}=0.05$ was computed to compare the total dry-matter yield among the sixteen cultivars. The AMMI model was applied to study the patterns of GEI and to graphically display means, adaptation and stability of alfalfa cultivars across environments. The AMMI model, which combines standard analysis of variance with PC analysis (Zobel et al., 1988), is a very effective method for investigating GEI. In the AMMI model, the contribution of each cultivar and each environment to the GEI was assessed by using the biplot graph display, in which yield means were plotted against the scores of the interaction principal component 1 (PCA1) (Zobel et al., 1988). The AMMI model was:

$\mathrm{Y}_{g e}=\mu+\alpha_{\mathrm{g}}+\beta_{\mathrm{e}}+\sum \lambda_{n} \zeta_{g n} \eta_{e n}+\theta_{g e}$

where $\mathrm{Y}_{g e}$, is the yield of genotype $(g)$ in environment $(e) ; \mu$ is the grand mean; $\alpha_{g}$ is the genotype mean deviation; $\beta_{e}$ is the environment mean deviation; $\lambda_{n}$ is the eigenvalue of the PCA axis $(n) ; \zeta_{g n}$ and $\eta_{e n}$ are the genotype and environment PCA scores for the PCA axis $(n)$; and $\theta_{g e}$ is the residual.

Biplot analysis is the most powerful interpretative tool of the AMMI model, where aspects of both genotypes and environments are plotted on the same axis, so that the inter-relationships can be visualised. Thus, Gauch et al. (2008) suggested that the AMMI-1 display of genotype nominal yields describes winning genotypes and adaptive responses simply and clearly.

Purchase et al. (2000) developed an approach called the AMMI stability value (ASV) and considered it as the most appropriate procedure to describe the stability of a genotype, which is based on the first (IPCA1) and second (IPCA2) interaction principal component axis scores of the AMMI model for each genotype. The

Table 1. Code, names, country of origin and target environments of sixteen alfalfa cultivars evaluated in four environments of Algeria.

\begin{tabular}{lcc} 
Cultivar & Origin & $\begin{array}{c}\text { Target environment/ } \\
\text { Selection purpose }\end{array}$ \\
$\begin{array}{l}\text { Sicilian ecotype } \\
\text { Prosementi }\end{array}$ & $\begin{array}{c}\text { Sicily (Italy) } \\
\text { Northern Italy }\end{array}$ & $\begin{array}{c}\text { Rainfed conditions } \\
\text { Moderately favourable conditions }\end{array}$ \\
\hline ABT 805 & Southeast USA & Grazing tolerance \\
Ameristand 801S & Southwest USA & Salt tolerance \\
\hline Mamuntanas & Sardinia (Italy) & Rainfed conditions \\
Tamantit & Southern Algeria & Irrigated areas (oasian) \\
\hline Sardi 10 & Southern Australia & Mild-winter conditions \\
Siriver & Southern Australia & Aphid tolerance, high-rainfall area \\
\hline Africaine & Morocco & Irrigated areas \\
Gabès 2355 & Tunisia & Irrigated areas (oasian) \\
\hline Magali & Southern France & Temperate conditions \\
Melissa & Southern France & Mild-winter conditions \\
\hline Coussouls & France & Grazing tolerance \\
Rich 2 & Morocco & Irrigated areas (oasian) \\
\hline Erfoud 1 & Morocco & Irrigated areas, salt tolerance \\
Demnat 203 & Morocco & Irrigated areas (oasian) \\
\hline
\end{tabular}


ASV is the distance from the origin to the genotype coordinate point in a two-dimensional plot of IPCA1 scores against IPCA2 scores. Genotypes with lowest ASV values have the shortest projection from the biplot origin and are considered as the most stable ones. ASV was computed as:

$$
\mathrm{ASV}=\sqrt{\left[\frac{S S_{I P C A 1}}{S S_{I P C A 2}}(I P C A 1 \text { score })\right]^{2}+(\text { IPCA2score })^{2}}
$$

where $\frac{S S_{I P C A 1}}{S S_{I P C A 2}}$, is the weight given to the IPCA1 value by dividing the IPCA1 sum of squares by the IPCA 2 sum of squares; and the IPCA1 and IPCA2 scores are the genotypic scores in the AMMI model. The statistical analyses were performed using the R package 'Agricolae' (software version 3.5.1) for AMMI analysis and ASV scores, and PBTools software (version 1.4) for the AMMI Biplot graph.

\section{Results}

Crop persistence was acceptable after four years of growth in three environments out of four, with a proportion of the fourth-year DMY to total DMY about equal to, or greater than, 25\% (Table 2). Only under rainfed conditions in Hmadna was the proportion equal to $15 \%$. Rainfed conditions resulted in $41.6 \%$ and $48.5 \%$ lower yield than irrigated ones in Alger and Hmadna, respectively. The subhumid location of Alger showed a much higher forage yield potential than the semi-arid location of Hmadna irrespective of the water management. Yield in Hmadna was 38.0\% and 45.2\% lower than in Alger under irrigated and rainfed conditions, respectively. Providing even a summer-withheld irrigation in Alger remarkably increased the forage yield potential of alfalfa in this location compared to rainfed conditions. At the opposite extreme, the combination of severe drought and high salinity stress substantially limited the yield potential in the Hmadna-rainfed environment (Table 2).

The ANOVA revealed highly significant variation $(\mathrm{P}<0.001)$ among cultivars and among environments for total DMY, as well as a significant GEI $(\mathrm{P}<0.001)$. The AMMI model showed that the mean square for the $\mathrm{PC} 1$ axis was over 3-fold higher than the mean square for the residual, while the PC1 axis accounted for $72.3 \%$ of the interaction sum of squares (SS), and the residual for the remaining $27.7 \%$. These values indicated that the AMMI model was very effective in summarising the interaction. The environment SS was 10 times larger than the genotype SS, and 16 times larger than the GEI SS, while the genotype SS was 1.5 times larger than the GEI SS. Only the first principal component PC1 was significant (data not reported), and the relative AMMI-1 biplot, which accounted for $70.7 \%$ of GEI variation, was displayed in Figure 1. Modeled adaptive responses were shown as cultivar nominal yields, that is, expected responses from which the environment main effect, with no influence on cultivar ranking, was subtracted (Annicchiarico et al., 2011). Outstanding cross-over interactions among top-yielding cultivars occurred across contrasting environments. The American cultivar Ameristand 801S was topyielding in Hmadna-irrigated (lowest environment PC1 score) and the Italian cultivar Mamuntanas in Alger-irrigated (highest PC1 score; Figure 1).

Table 2. Geographic, climatic and soil information of the two test locations, and water management, mean annual irrigation, total dry matter yield (DMY) over a four-year crop cycle of sixteen alfalfa cultivars, and proportion of the fourth-year DMY to total DMY, of four test environments in the two locations.

\begin{tabular}{|c|c|c|c|c|}
\hline Location (Area) & & Alger (Coastal Algeria) & \multicolumn{2}{|c|}{ Hmadna (Inland Algeria) } \\
\hline Geographic position & & Mitidja plain & \multirow{2}{*}{\multicolumn{2}{|c|}{$\begin{array}{l}\text { Lower-Cheliff plain } \\
\qquad 48\end{array}$}} \\
\hline Altitude (m a.s.l.) & & 50 & & \\
\hline Latitude & & $36^{\circ} 45^{\prime} \mathrm{N}$ & \multicolumn{2}{|r|}{$35^{\circ} 54^{\prime} \mathrm{N}$} \\
\hline Longitude & & $3^{\circ} 14^{\prime} \mathrm{E}$ & \multicolumn{2}{|r|}{$0^{\circ} 46^{\prime} \mathrm{E}$} \\
\hline Climate & & Mediterranean sub-humid & \multicolumn{2}{|c|}{ Mediterranean semi-arid } \\
\hline Minimum and maximum of annual rainfall during the trials & $(\mathrm{mm})$ & 610 to 750 & \multicolumn{2}{|r|}{227 to 337} \\
\hline Annual average of minimum and maximum daily temperatu & $\mathrm{e}\left({ }^{\circ} \mathrm{C}\right)$ & $5.3-31.6$ & \multicolumn{2}{|r|}{$9.2-30.7$} \\
\hline Average daily maximum temperatures $\left({ }^{\circ} \mathrm{C}\right)$ in summer $(\mathrm{Ju}$ & e-August) & 35.1 & \multicolumn{2}{|r|}{37.6} \\
\hline Soil texture & & Loamy clay & \multicolumn{2}{|r|}{ Loamy clay } \\
\hline Soil pH $\left(\mathrm{H}_{2} \mathrm{O}\right)$ & & 7.70 & \multicolumn{2}{|r|}{7.97} \\
\hline Environment name & Alger-irrigated & Alger-rainfed & Hmadna-irrigated & Hmadna-rainfed \\
\hline Environment code & E1 & E2 & E3 & E4 \\
\hline Water management & Withheld irrigation $^{\mathrm{a}}$ & Rainfed & Withheld irrigation $^{\mathrm{a}}$ & Rainfed \\
\hline Annual irrigation (mm) & 150 & - & 245 & - \\
\hline Mean annual water available (mm) (rainfall + irrigation) & 862 & 712 & 528 & 283 \\
\hline Mean April-September water (mm) & 286 & 136 & 357 & 113 \\
\hline Soil electrical conductivity ${ }^{\mathrm{b}}(\mathrm{EC}) \mathrm{dS} \mathrm{m}^{-1}$ & 1.90 & 1.90 & 6.00 & 5.20 \\
\hline Number of cuts over the 4-year period & 19 & 11 & 18 & 12 \\
\hline Total DMY $\left(\mathrm{t} \mathrm{ha}^{-1}\right)$ & 43.25 & 25.24 & 26.82 & 13.82 \\
\hline Fourth year/total DMY proportion & 0.30 & 0.24 & 0.24 & 0.15 \\
\hline
\end{tabular}

aIn summer (for nine weeks); ${ }^{\mathrm{O}} \mathrm{On} 0-30 \mathrm{~cm}$ soil samples. 
In fact, Ameristand $801 \mathrm{~S}$ and Mamuntanas had highest yield in Hmadna and Alger location, respectively, regardless of the water management. Exotic cultivars generally had a positive response towards more favourable environments (Alger location), whereas North-African landraces tended to better response at low environment PC1 score (Hmadna location). The response of Erfoud 1 was particularly interesting, suggesting a specific adaptation pattern to this salt-stressed location of Hmadna (Figure 1). The Algerian cultivar Tamantit was more productive in the Hmadnairrigated environment than in the other environments. This cultivar originated from an oasis with arid climate and high salinity and showed full intolerance to the sub-humid climate of Alger (Figure 1). The Italian cultivar Sicilian ecotype tended to a stable and relatively high yield across all environments, while the French cultivar Magali was rather stable but with intermediate yield levels. Prosementi, selected for moderately-favorable conditions of northern Italy, was characterised by medium to poor adaptation across environments (Figure 1).

The recorded 4-year total DMY of the cultivars ranged from $19.49 \mathrm{t} \mathrm{ha}^{-1}$ for Tamantit to $31.64 \mathrm{t} \mathrm{ha}^{-1}$ for Ameristand 801S, with an average of $27.28 \mathrm{tha}^{-1}$ (Table 3 ). The four top-ranking cultivars (exceeding $30 \mathrm{t} \mathrm{ha}^{-1}$ ) were all exotic cultivars, while the four bottom-ranking ones $\left(<25 \mathrm{tha}-{ }^{1}\right)$ were all North-African landraces (Table 3).

The remarkable stability in the presence of a good forage yield, previously noticed for Sicilian ecotype in the graphical representation of the AMMI analysis, was also confirmed by the

Table 3. Mean total dry-matter yield of $\mathbf{1 6}$ alfalfa cultivars across four environments of evaluation, and additive main effects and multiplicative interaction stability value.

\begin{tabular}{lcc} 
Cultivar & DMV $\left(\mathrm{t} \mathrm{ha}^{-1}\right)$ & ASV \\
Sicilian ecotype & $30.63^{\text {abc }}$ & 0.87 \\
Magali & $27.92^{\text {cde }}$ & 0.95 \\
\hline Gabès 2355 & $24.89^{f g}$ & 1.13 \\
Siriver & $28.27 \mathrm{cde}$ & 1.14 \\
\hline Melissa & $27.46^{\text {def }}$ & 1.16 \\
Sardi 10 & $30.01^{\text {abcd }}$ & 1.44 \\
\hline Prosementi & $26.29^{\text {ef }}$ & 1.54 \\
Africaine & $22.01^{\text {hi }}$ & 1.55 \\
\hline Erfoud 1 & $28.42^{\text {cde }}$ & 1.65 \\
Rich 2 & $26.68^{\text {ef }}$ & 1.72 \\
\hline Coussouls & $28.48^{\text {bcde }}$ & 1.93 \\
Demnat 203 & $23.43^{\text {gh }}$ & 2.14 \\
\hline ABT 805 & $29.54^{\text {abcd }}$ & 2.16 \\
Ameristand $801 S$ & $31.64^{\text {a }}$ & 2.18 \\
\hline Mamuntanas & $31.31^{\text {ab }}$ & 2.96 \\
Tamantit & $19.49^{\mathrm{i}}$ & 5.49 \\
\hline LSD (P=0.05) & 2.85 & - \\
\hline DMY, dry-matter yield; ASV, additive main effects and multiplicative interaction stability value; LSD, least \\
significant difference test.-i-Mean total DMY values followed by different letters were different accord- \\
ing to the least significant difference (LSD) at P=0.05.
\end{tabular}

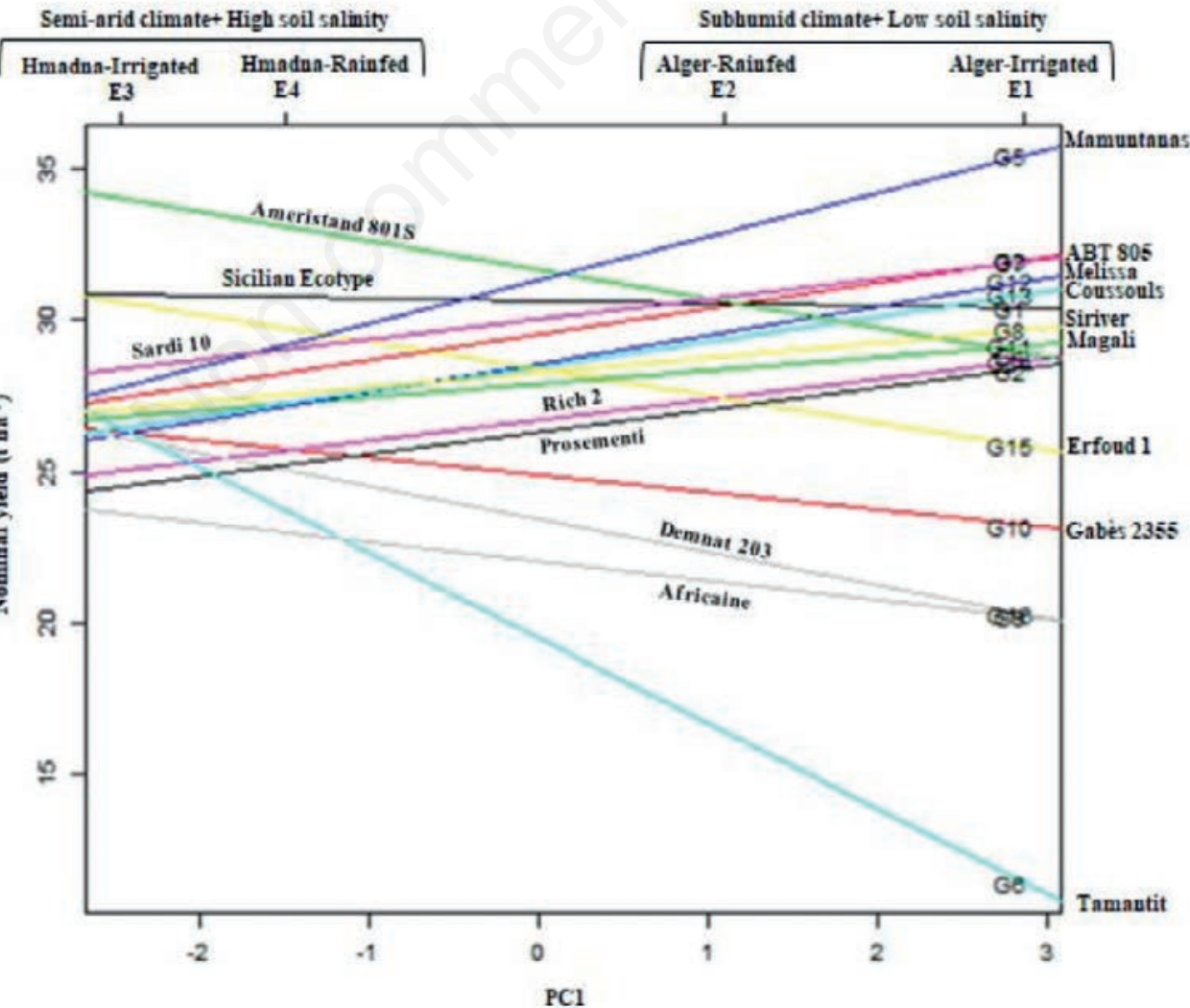

Figure 1. Nominal four-year dry matter yield of 16 alfalfa cultivars as a function of the environment score on the first genotype $\times$ environment interaction (GEI) principal component (PC1) axis (PC1 $=70.7 \%$ of total GEI variation). 
ASV score and mean DMY of this cultivar across environments (Table 3). The ASV score also confirmed the great responsiveness (that is, little stability) of Mamuntanas and Ameristand 801S in their respective environment of adaptation (Figure 1), and the marked instability of Tamantit because of its mentioned failure in the subhumid location of Alger. Other cultivars showing low ASV score, such as Magali and Gabès 2355 (Table 3) were characterised by intermediate performance across environments (Figure 1).

\section{Discussion}

A $42 \%$ yield reduction in rainfed cropping compared to irrigated trials was observed by Annicchiarico et al. (2011) who tested the same set of cultivars across several environments. The present results from Alger confirmed this more general trend, while a somehow greater reduction was observed in the semi-arid, salinity-prone location of Hmadna. The salinity level recorded in this location largely exceeded the threshold value for yield decrease estimated in $2.0 \mathrm{dS} \mathrm{m}^{-1}$ in alfalfa (Grieve et al., 2012) and the salinity stress exacerbated the drought effects. Salinity effects in cool and humid weather are more tolerable by plants than in hot or dry weather (Peverill et al., 1999).

Bouizgaren et al. (2013) also evaluated the same set of cultivars in a semi-arid region of Morocco, comparing the yield under a summer-withheld irrigation (water management similar to the present one) versus the yield under continuous irrigation (oasis treatment), and reported a yield reduction ranging between $23.9 \%$ and $42.6 \%$ with withheld irrigation. Further investigations could possibly help assessing whether the least reduction levels in forage yield caused by withholding the summer irrigation in alfalfa could be paid back using the saved irrigation water in summer for other crops with higher added value (e.g., orchards or vegetables). Reducing or withholding irrigation during the period of lowest water-use efficiency (summer months) might be an important solution for water conservation, provided that suitable stress-tolerant germplasm is identified.

The present adaptation patterns were consistent with previous results. Pecetti et al. (2013) highlighted the high salt tolerance of both Ameristand 801S and Erfoud 1 and suggested that the NorthAfrican landraces could be interesting salt-tolerant genetic resources. Landraces or varieties selected under rainfed conditions in southern Europe, USA and Australia could be sources of drought tolerance (Pecetti et al., 2008; Annicchiarico et al., 2013), such as Sicilian ecotype, which evolved under rainfed cropping and moderate annual rainfall. Studies carried out in south Tunisia also indicated a possible yield advantage of exotic cultivars over local germplasm, especially in the absence of a full irrigation management (Hayek et al., 2008; Benabderrahim et al., 2015). The good performance of Mamuntanas, Ameristand 801S, Erfoud 1 and Sicilian ecotype, and the lower yield of the North-African landraces were also reported by Bellague et al. (2016) in a study based on yield and stress tolerance index. The Australian cultivar Sardi 10 was top yielding under dryland Mediterranean environments of Chile (del Pozo et al., 2017).

The Algerian landrace Tamantit is featured by a high sensitivity to different pests and pathogens and it is not adapted to humid conditions (Aomari, 2011). However, Tamantit and Gabès 2355 produced better (about $30 \mathrm{t} \mathrm{ha}^{-1} \mathrm{DM}$ over two years) than introduced varieties such as Magali (from France) and Lodi (from Italy) in the oasis of Adrar because of their high tolerance to the thermal stress caused by maximum temperature of $50^{\circ} \mathrm{C}$ (Bouaboub-
Mossab, 2001). Climatic and soil conditions appeared to be a major determinant of the variation in cultivar response in this study. As Algeria is largely characterised by low and irregular rainfall, while salt-affected soils are also widespread, drought- and salt-tolerant cultivars should be selected to ensure appreciable yields. Stable yields are also needed under such unpredictable conditions. The application of the AMMI model facilitated the visual comparison and identification of the most adapted cultivar(s) in each target environment. Cultivars such as Ameristand 801S, Sicilian ecotype and Erfoud 1 could be recommended in salinityaffected areas such as Hmadna. Mamuntanas, Sardi 10, Sicilian ecotype and ABT 805 seemed best adapted in moderately favourable environments such as Alger. The Italian cultivar Sicilian ecotype had an acceptable and stable yield across environments. However, similar experiments should be envisaged on a wider scale across Algeria to better assess the adaptation and stability of alfalfa germplasm, which could serve as a basic breeding material to develop new drought- and salt-tolerant varieties.

\section{References}

Abdelguerfi A, Laouar M, 2002. Les espèces fourragères et pastorales, leurs utilisations au Maghreb (Algérie, Maroc, Tunisie). Editions Organisation des Nations Unies pour l'alimentation et l'agriculture (FAO), Bureau régional de la FAO pour le Proche-Orient et l'Afrique du Nord.

Alessandri A, De Felice M, Zeng N, Mariotti A, Pan Y, Cherchi A, Lee JY, Wang B, Ha KJ, Ruti P, Artale V, 2014. Robust assessment of the expansion and retreat of Mediterranean climate in the 21st century. Sci. Rep. 4:7211.

Annicchiarico P, 2002. Genotype $\times$ environment interactions: challenges and opportunities for plant breeding and cultivar recommendations. Food and Agriculture Organization of the United Nations (FAO) Plant Production and Protection, Paper No. 174, Rome, Italy.

Annicchiarico P, Pecetti L, Abdelguerfi A, Bouizgaren A, Carroni AM, Hayek T, M'Hammadi-Bouzina M, Mezni M, 2011. Adaptation of landrace and variety germplasm and selection strategies for lucerne in the Mediterranean basin. Field. Crop. Res. 120:283-91.

Annicchiarico P, Pecetti L, Tava A, 2013. Physiological and morphological traits associated with adaptation of lucerne (Medicago sativa) to severely drought-stressed and to irrigated environments. Ann. Appl. Biol. 162:27-40.

Annicchiarico P, Barrett B, Brummer EC, Julier B, Marshall AH, 2015. Achievements and Challenges in Improving Temperate Perennial Forage Legumes. Crit. Rev. Plant. Sci. 34:327-80.

Aomari O, 2011. Comportement de seize cultivars de luzerne pérenne (Medicago sativa L.) en essai pluvial et irrigué au niveau de la Mitidja. Degree Magister, Ecole Nationale Supérieure Agronomique of Algiers, Algeria.

Ballesta A, Lloveras J, 2010. Nitrogen replacement value of alfalfa to corn and wheat under irrigated Mediterranean conditions. Span. J. Agric. Res. 8:159-69.

Barrios PG, Castro M, Pérez O, Vilaró D, Gutiérrez L, 2017. Genotype by environment interaction in sunflower (Helianthus annus L.) to optimize trial network efficiency. Span. J. Agric. Res. 15:19.

Bellague D, M'Hammedi-Bouzina M, Abdelguerfi A, 2016. Measuring the performance of perennial alfalfa with drought tolerance indices. Chil. J. Agr. Res. 76:273-84. 
Benabderrahim MA, Haddad M, Hamza H, Ferchichi A, 2011. Germination and emergence variability of alfalfa (Medicago sativa L.) landraces collected in Southern Tunisia oases. Span. J. Agric. Res. 9:135-43.

Benabderrahim MA, Hamza H, Mansour H, Ferchichi A, 2015. A comparison of performance among exotic and local alfalfa (Medicago sativa L.) ecotypes under Tunisian conditions. Rom. Agric. Res. 32:43-51.

Bouaboub-Mossab K, 2001. Comportement de variétés et populations de luzerne pérenne (Medicago sativa L.). Degree Magister, Institut National Agronomique of Algiers, Algeria.

Bouizgaren A, Farissi M, Ghoulam C, Kallida R, Faghire M, Barakate M, Al Feddy MN, 2013. Assessment of summer drought tolerance variability in Mediterranean alfalfa (Medicago sativa L.) cultivars under Moroccan fields conditions. Arch. Agron. Soil. Sci. 59:147-60.

Chedjerat A, M'Hammedi-Bouzina M, Gacemi A, Abdelguerfi A, 2016. Forage yield components of various alfalfa (Medicago sativa L.) cultivars grown on salt-a $\square$ ected soil under rainfed and irrigated conditions in a Mediterranean environment. J. Agric. Res. 11:3246-53.

del Pozo A, Ovalle C, Espinoza S, Barahona V, Gerding M, Humphries A, 2017. Water relations and use-efficiency, plant survival and productivity of nine alfalfa (Medicago sativa L.) cultivars in dryland Mediterranean conditions. Eur. J. Agron. 84:16-22.

Fagnano M, Maggio A, 2018. On the interactions among tropospheric ozone levels and typical environmental stresses challenging Mediterranean crops. Environ. Sci. Pollut. R. 25:8174-80.

Gauch HG, 2006. Statistical analysis of yield trials by AMMI and GGE. Crop. Sci. 46:1488-500.

Gauch HG, Piepho HP, Annicchiarico P, 2008. Statistical analysis of yield trials by AMMI and GGE: Further considerations. Crop.
Sci. 48:866-89.

Grieve CM, Grattan SR, Maas EV, 2012. Plant salt tolerance. In: W. W. Wallender and K. K. Tanji (Eds.), Agricultural Salinity Assessment and Management ( $2^{\text {nd }}$ edition). ASCE, Resto, VA, USA, pp 405-59.

Hayek T, Loumerem M, Nagaz K, Thabet M, 2008. Growth development and dry matter yield of 16 Lucerne genotypes cultivated in south Tunisia. Options Méditerranéennes Series A, 79:299-302

Pecetti L, Carroni AM, Annicchiarico P, Manunza P, Longu A, Congiu G, 2008. Adaptation, summer survival and autumn dormancy of lucerne cultivars in a south European Mediterranean region (Sardinia). Options Méditerranéennes Series A 79:471-4.

Pecetti L, Annicchiarico P, De Rosa L, Proietti S, 2013. Targeting lucerne cultivars to saline-soil environments. In: S. Barth and D. Milbourne (ed.) Breeding strategies for sustainable forage and turf grass improvement. Springer, Dordrecht, The Netherlands, pp 249-53.

Peverill KI, Sparrow LA, Reuter DJ, 1999. Soil analysis: an interpretation manual. CSIRO Publishing, Collingwood, Vic.

Purchase JL, Hatting H, Van Deventer CS, 2000. Genotype $\times$ environment interaction of winter wheat (Triticum aestivum L.) in South Africa: II. Stability analysis of yield performance. S. Afr. J. Plant. Soil. 17:101-7.

Small E, 2010. Alfalfa and relatives: Evolution and classification of Medicago. NRC Research Press, Ottawa, and CAB International, Wallingford.

Volaire F, Barkaoui K, Norton M, 2014. Designing resilient and sustainable grasslands for a drier future: adaptive strategies, functional traits and biotic interactions. Eur. J. Agron. 52:81-9.

Zobel RW, Wright MJ, Gauch HG, 1988. Statistical analysis of a yield trial. Agron. J. 80:388-93. 